Revue

Revue de l'histoire des religions

de Ihistoire des religions

$3 \mid 2006$

Varia

\title{
Comte Paul Riant, Exuviae sacrae
}

\section{Constantinopolitanae}

vol. I et vol. II, préface de J. Durand, Paris, Éditions du Comité des

Travaux Historiques et Scientifiques, 2004

John Wortley

\section{OpenEdition}

\section{Journals}

Electronic version

URL: http://journals.openedition.org/rhr/5176

DOI: 10.4000/rhr.5176

ISSN: 2105-2573

Publisher

Armand Colin

Printed version

Date of publication: 1 September 2006

Number of pages: $350-351$

ISBN: 2200-92105-5

ISSN: 0035-1423

Electronic reference

John Wortley, "Comte Paul Riant, Exuviae sacrae Constantinopolitanae », Revue de l'histoire des religions [Online], 3 | 2006, Online since 22 January 2010, connection on 22 September 2020. URL : http:// journals.openedition.org/rhr/5176 ; DOI : https://doi.org/10.4000/rhr.5176

This text was automatically generated on 22 September 2020

Tous droits réservés 


\section{Comte Paul Riant, Exuviae sacrae Constantinopolitanae}

vol. I et vol. II, préface de J. Durand, Paris, Éditions du Comité des Travaux Historiques et Scientifiques, 2004

John Wortley

\section{REFERENCES}

Comte Paul Riant, Exuviae sacrae Constantinopolitanae, vol. I et vol. II, préface de J. Durand, Paris, Éditions du Comité des Travaux Historiques et Scientifiques, 2004, $22 \mathrm{~cm}$, 43-CCXXIV-196 p. (vol. I) et XX-401 p. (vol. II), (« CTHS Histoire » 19), $78 €$ chaque volume.

1 Exuviae can mean both the armour stripped from the defeated and also "special attributes of gods carried in processions", hence it is a most appropriate title for this work which is mainly concerned with the holy relics which the participants in the Fourth Crusade carried off from the vanquished capital on the Bosporus. They took a great deal else beside relics of course, but the relics were of particular importance, partly because (as A. Frolow argued in 1954) the relics may have been largely responsible for the so-called "diversion" of the Fourth Crusade from the Holy Land to the New Rome, partly because, once they arrived in the west, relics tended to maintain their characteristics, and not to be subsumed into general revenue like other assets.

2 From the mid-fourth century relics played a significant role in Byzantine piety. Partly thanks to the initiative of some emperors, partly due to private munificence (and some malfeasance), Byzantium gradually came to house the largest, perhaps the most varied, and certainly the most famous collection of relics in Christendom. The process may have been complete by the end of the tenth century, by which time the New Rome had not only eclipsed the Old one, but also Jerusalem and the Holy Land, in the wealth of its holy objects. The extent of this relic-hoard was already becoming known in the west in the eleventh century (as pilgrims stopped by on their way east); with the passing of the 
First Crusade in 1096 it became famous, while by the Fourth it was ravished. In Exuviae Riant provided the scholarly world with a tool which remains indispensable for all who study that hoard or try to understand the complexities of the Fourth Crusade. In it he set himself to assemble all the available documentation relevant to the hoard, first to how it stood before 1204, secondly to how, why and where it was dispersed. Although the extent of the hoard was widely known to have been enormous, it was Riant's dossier which, for the first time, established the staggering extent of its enormity. The Byzantine sources do of course from time to time mention the arrival of this or that relic (especially in the earlier centuries) and rarely fail to record the acquisition of the more significant pieces (such as the Sacred Mandyllion from Edessa in 944), but these records are very far from complete, even for the imperial collection housed in the Palace Chapel of the Lighthouse [tou Pharou] where most of the really significant items were conserved. (The first comprehensive list of its major items is in a western source.) From the documentation assembled by Riant one learns of numerous relics of whose arrival there is no extant report; not even a hint of its existence in the liturgical evidence either.

Riant's main concern, however, looks forward rather than backward: to what became of each relic as it journeyed westward, and here his work is of greater value to western medievalists that to Byzantinists. He was not the first to have undertaken such an enquiry; DuCange's Traité historique du chef de saint Jean-Baptiste published at Paris in 1665 is an obvious fore-runner, while his own edition of Robert de Clari's Li estoires de chiaus qui conquisent Constantinoble was already in print. Riant was nevertheless the first to assemble all the extant documentation, thus bringing to light a considerable amount of previously unpublished material as well as much which would otherwise be scarcely accessible. Inevitably time has left some of his pieces unsatisfactory. We now have (for instance) at least two superior editions of the co-called "Letter of Alexis I to Robert of Flanders", two better translations of Antony of Novgorod's Pilgrim Book. More to the point, we now have sources which were unknown to Riant, such as the so-called "Anon. Mercati", "Une description de Constantinople traduite par un pèlerin anglais" (Revue des Études Byzantines, 34, 1976, p. 211-267), and the other invaluable texts edited by Krijnie N. Cigaar. Yet for all this, as was acknow-ledged at a Table ronde on "Byzantium and the relics of Christ" at the $20^{\text {th }}$ International Congress for Byzantine Studies in 2001, Riant's dossier remains indispensable. For this reason alone the re-appearance of Exuviae (albeit bereft of its original fine binding) is a welcome event, but there is considerably more. The dossier itself is preceded by a Preface of 224 pages, written in French (whereas the dossier is entirely in Latin). In seven chapters and a conclusion, Riant here examines in great detail the ways in which the source-material is to be handled. This is a masterly introduction, maybe even one somewhat ahead of its time, to the theory and practice of the histo-rian's craft; its value is fully explored in the excellent Introduction (vol. 1, p. 7-43) which Janic Durand has supplied for this reprint.

4 A third volume was added to Exuviae by Ferdinand de Mély, subtitled: "La croix des premiers croisés; la sainte lance; la sainte couronne" (Paris, 1904) but this has largely been superseded by such works as Anatole Frolow, La relique de la Vraie Croix: recherches sur le développement d'un culte ("Archives de l'Orient Chrétien", 7, Paris, 1961) hence the omission of de Mély's volume from the reprint is no severe loss. 


\section{AUTHORS}

JOHN WORTLEY

University of Manitoba, Canada 